\title{
Habitat use of common dolphin (Delphinus sp.) in the Mochima National Park, Sucre, Venezuela
}

\author{
Alimar Molero-Lizarraga ${ }^{1}$; Guillermo R. Barreto ${ }^{2}$ and Sergio Cobarrubia-Russo ${ }^{2,3}$ \\ Contact e-mail: alimarelena@gmail.com
}

\begin{abstract}
The common dolphin (Delphinus sp.) is one of the most common cetaceans in Venezuela. This study aims to describe habitat use in the Mochima National Park, a protected area under high anthropogenic pressure. Opportunistic surveys were conducted following a pre-defined route from September 2009 to August 2010. Data such as the geographical position, group size, composition, behaviour were recorded at $5 \mathrm{~min}$ intervals. A focal group-follow methodology was used. A grid of $500 \times 500 \mathrm{~m}$ was constructed and each cell was characterised by environmental features and a Coefficient of Area Use (CAU) was calculated. A logistic regression model was applied to identify factors that explain use pattern. Seventy opportunistic surveys were conducted during which 86 groups of dolphins were observed. Dolphins occupied an area of $36 \mathrm{~km}^{2}$, but Tigrillo inlet and to the northeast of the Caracas Islands were the areas most used. The common dolphins exhibited differential use, using shallow inshore waters most intensively and with probability of occurrence decreasing with increasing water depth and distance to the coast. They spent most of their time in feeding $(40 \%)$ and socialising (24\%) activities. Feeding and travelling behaviours were observed throughout the area studied, whereas socialising and resting activities were mainly concentrated in Tigrillo inlet, the Manare peninsula and the Caracas islands. Behaviour was mostly determined by season, depth, distance to the coast, group size and group composition. Throughout the year, the Park provided areas for refuge, feeding, and resting. It is therefore imperative to promote management and conservation policies that prevent any negative impacts from the increasing tourism and fishing activities we observed.
\end{abstract}

KEYWORDS: COMMON DOLPHIN; HABITAT; MONITORING; MODELLING; CARIBBEAN SEA; SOUTH AMERICA

\section{INTRODUCTION}

The term 'habitat use' refers to how an animal uses the physical and biological resources within a habitat (Krausman, 1999). A habitat can be used for feeding, refuge, mating and many other things. In some cases, an area that is used for foraging could also have the physical features required for refuge (Krausman, 1999). Differential use of habitat has been described in several taxonomic groups (Rivero et al., 2005; Fischhoff et al., 2007; Garaffo et al., 2007; Kofoky et al., 2007; Ryan et al., 2008). Factors influencing habitat use vary according to species, but in general each species searches for environmental features that are directly or indirectly associated with the resources it would need for reproduction and survival (Krausman, 1999).

\footnotetext{
${ }^{1}$ Unidad de Diversidad Biológica, Instituto Venezolano de Investigaciones Científicas IVIC, 1020-A Caracas, Venezuela.

${ }^{2}$ Laboratorio de Manejo y Conservación de Fauna Silvestre, Departamento de Biología de Organismos, Universidad Simón Bolívar, Apartado 89000, 1080-A Caracas, Venezuela.

${ }^{3}$ Laboratorio de Ecología Acuática, Centro de Ecología, Instituto Venezolano de Investigaciones Científicas, Apartado Postal 20632, 1020-A

Caracas, Venezuela.
} 
To identify the factors that determine habitat preference, it is important to understand the ecological interactions between organisms and their environment (Beyer et al., 2010). Understanding these interactions will help with identifying ecologically important areas (Johnson, 2000; Manly et al., 2002), which is fundamental for identifying areas that are suitable for environmental protection and mitigation from anthropogenic impacts (Dawson and Slooten, 1993; Hooker et al., 1999; Hastie et al., 2003). According to Wedekin et al. (2002), studies of habitat use and behaviour are important for conservation planning.

Common dolphins (genus Delphinus) are among the most widely distributed cetaceans, occurring across tropical, subtropical and temperate oceanic waters. They occupy a wide range of habitats, from nearshore areas to open ocean (Gaskin, 1968; Hui, 1979; Au and Perryman, 1985; Seltzer and Payne, 1988; Evans 1994; Ferrero and Walker, 1995; Bearzi, 2005; Acevedo, 2007; Filby et al., 2010; Tavares et al. 2010; Bilgman et al., 2018).

In Venezuela, common dolphins (Delphinus sp.) are distributed along the northeastern coast. They are the most frequently observed cetacean species in this area. To date, studies on this dolphin (Romero et al., 2001; Quevedo, 2004; Molero, 2005; Rangel et al., 2005; Acevedo, 2007; Bermúdez-Villapol and Sayegh, 2007; Esteves and Oviedo, 2007; Rangel and Cobarrubia, 2008; Oviedo et al., 2010) have reported that common dolphins often use shallow waters $(<100 \mathrm{~m})$ and spend a lot of time travelling. Recent abundance estimates for this species (Oviedo et al., 2010), indicate that common dolphins are abundant across the whole of the northeast coast. This information is of interest as this species of dolphin is the main target for dolphin watching (Bolaños-Jiménez et al., 2007) and whilst common dolphins are not classified as endangered, they do face a number of human threats.

The taxonomic identity of the Venezuelan stock of common dolphins remains controversial (Esteves and Oviedo 2007; Jefferson et al., 2009; Tavares et al., 2010; Committee on Taxonomy, 2019). Therefore, we refer to the common dolphin addressed in this research as Delphinus sp., under the premise that taxonomic identity will be resolved in the future.

The Mochima National Park is a natural area of abundant marine biodiversity which makes it ideal for tourism and commercial fishing (Suarez and Bethencourt, 1994; Miloslavich et al., 2003; Alvarez, 2015). In recent years, the Park has been under high anthropogenic pressure from such as fishing, vessel traffic, pollution and tourism (Rivero Blanco et al., 2001; Linares, 2016), which may be affecting its biodiversity. The aim of this study is to look at the habitat use of Delphinus sp., by identifying the environmental variables associated with their presence. It is also important to look at the habitat used in relation to group size and composition, as well as to the behaviour observed on the surface.

\section{MATERIALS AND METHODS}

\section{Study area}

The study area was located in the Mochima National Park on the northeastern coast of Venezuela, South America $\left(10^{\circ} 10.31^{\prime} \mathrm{N}, 64^{\circ} 13.4^{\prime} \mathrm{W}\right.$ and $\left.10^{\circ} 25^{\prime} \mathrm{N}, 64^{\circ} 42.9^{\prime} \mathrm{W}\right)$ (see Fig. 1). Its edge is located at depths of $84 \mathrm{~m}$ to $125 \mathrm{~m}$ with slopes from 0 to $3^{\circ}$ (Miró, 1974). It has a semi-arid climate with a dry season from January to May and a rainy season from June to December. The study area presents a cyclic variation related to the coastal upwelling phenomenon of the area. This can be seen by looking at the temperature, dissolved oxygen, salinity, $\mathrm{pH}$ and water clarity (Robaina, 1991).

\section{Data collection}

Opportunistic surveys were conducted in the morning from 07:00 to 12:00 hours (local time) from September 2009 to August 2010. The surveys followed a pre-defined route in the east of the Mochima National Park (Fig. 1). A $5 \mathrm{~m}$ artisanal boat with a 40hp outboard motor was used to conduct the surveys. The average speed of the vessel was $15 \mathrm{~km} / \mathrm{h}$ and the mean duration of the surveys was 5 hours. Binoculars (Look Mariner Series LK750P, 7x50mm) were used to locate the animals.

For the purposes of the study, a group of dolphins was established as the sample unit (Shane, 1990). A group was defined as an ensemble of animals closely engaged in the same activity and moving in the same direction (Garaffo et al., 2007). When a group was found, the pre-defined route was abandoned and the group was followed for as long as possible, to a maximum of 30 minutes. Data such as geographic position, group size, 


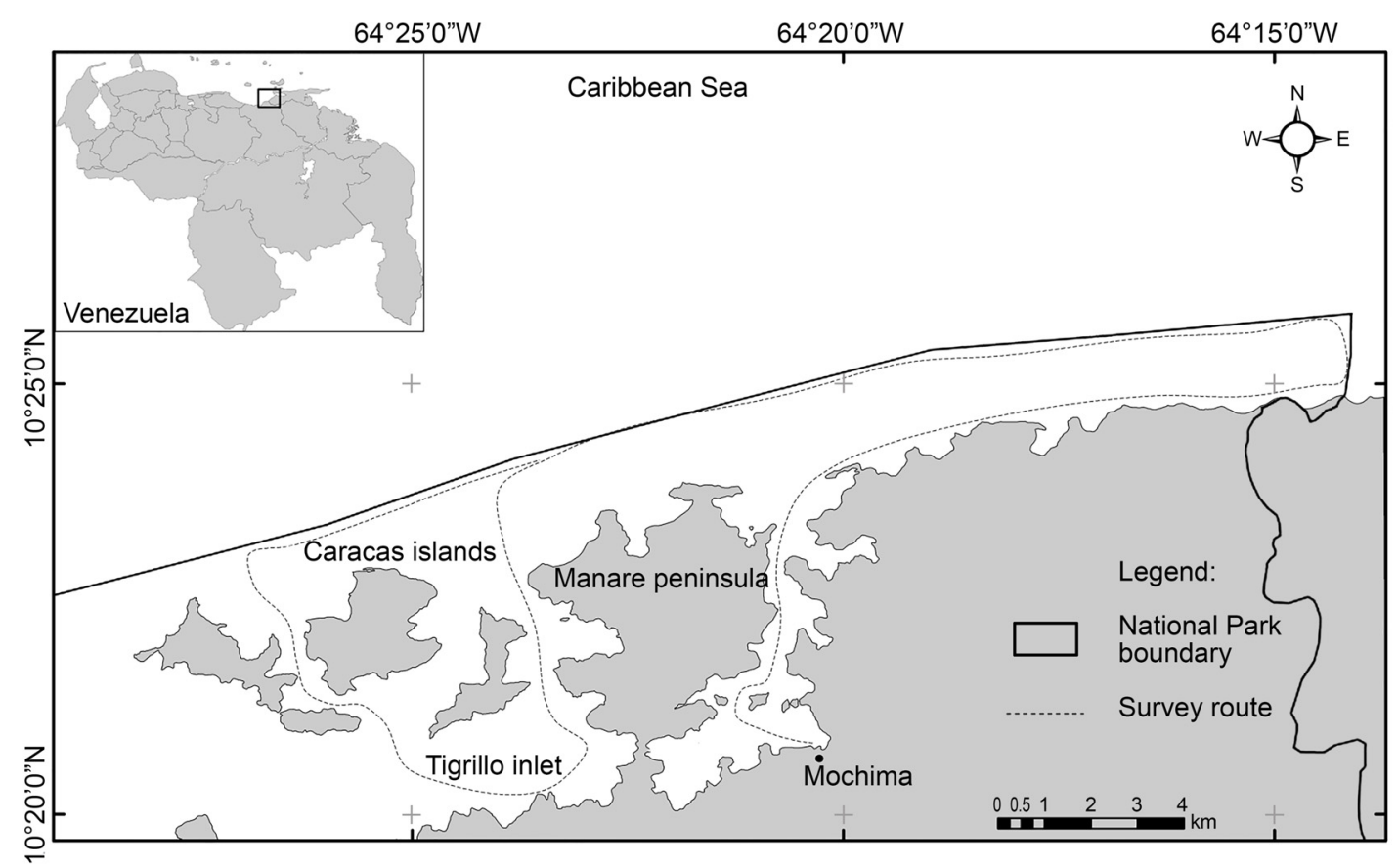

Fig. 1. Map of the study area which includes the park boundary and survey route. Surveys were done from Mochima town.

behaviour, and group composition were collected in blocks of five minutes when following a group of dolphins. When the 30 minute monitoring period ended, the survey was put on hold for two hours before the next recording to minimise the risk of auto-correlated data. This interval was chosen based on:

(1) the time necessary for an animal to transverse its home range (Swihart and Slade, 1985);

(2) data on Delphinus delphis swimming speeds; and

(3) he distance that can be travelled within that period (Hui, 1987; Rohr et al., 2002).

A photographic record of each group was made, using a digital reflex camera (Nikon D80) with an 18-200mm zoom lens, to identify group members individually (Wilson et al., 1999). Photo-ID focused mainly on capturing the dorsal fins of the dolphins. Individual identification prevented each group from being followed more than once during a day of sampling.

\section{Behaviour}

We recorded behaviour patterns using the focal group sampling criteria (Altmann, 1974; Mann, 1999). Each group was observed from left to right to include all individuals (Mann, 1999). A behaviour was considered 'predominant' if at least $50 \%$ of the animals were engaged in it at the time of observation. Each group's size and composition were also recorded.

Four behaviour states were considered:

(a) Feeding - short and unsynchronised dives, abundant surface events, multidirectional movements and, often, the presence of seabirds and schooling fish;

(b) Travelling - moving steadily in one direction, with synchronised dives;

(c) Socialising - Individual interactions within a group, frequent physical contact, often with vigorous movements and aerial behaviours such as leaping and breaching. This also included sexual and aggressive behaviours; and

(d) Resting - very slow movements or stationary at the surface (Norris and Dohl, 1980, Shane, 1990; Viddi and Lescrauwaet, 2005). 
Group sizes were categorised at five size intervals (1-20, 21-40, 41-60, 61-80, and greater than 80 animals). According to their composition, groups were classified (Garaffo et al., 2007) as (a) adult-juvenile, (b) juvenile, (c) mother with calves (more than $80 \%$ of the individuals were mothers with their calves) and (d) mixed (combination of mother with calves, juveniles and adults); the calves being dolphins less than half the length of an adult and in close association with an adult (Fertl, 1994); a juvenile being approximately two-thirds of the size of an adult who is frequently observed swimming in association with adults but not in the typical position of a calf (Mann et al., 2000). Adults were defined as any animal not classified as a calf or juvenile. These latter were animals that appeared to be fully grown individuals $(180-220 \mathrm{~cm}$ in length), physically mature but not necessarily sexually mature (Collet and St Girons, 1984).

\section{Environmental variables}

Every time a group was sighted, we determined its geographical location using a GPS receiver and plotted on a nautical chart (DHN N 24433, 1:39.940). We drew a grid by using the Grids and Graticules extension of the ArcGIS 10.3 programme. The grid was composed of 30 rows and 58 columns with a cell size of $500 \times 500 \mathrm{~m}$, the grid covered the entire study area. At each location, the depth, distance to the coast, and slope were measured. Depth was obtained by interpolation of points from the nautical chart. The distance to the coast was calculated by measuring from the centre point of each cell to the point closest to the coast. The slope was calculated in each cell using the following formula:

$$
S=\frac{D_{\max }=D_{\min }}{D I}
$$

where $D_{\max }$ is the maximum depth in the cell, $D_{\min }$ is the minimum depth in the cell, and DI is the distance in meters between the points of maximum and minimum depth of the cell, expressed in units of metres per kilometre (Cañadas et al., 2002). All of the variables measured during the fieldwork were recorded on a digital voice recorder (Olympus VN-3100PC) and later transcribed to a database.

\section{Data analysis}

To determine habitat use, each cell was characterised by dolphin use intensity. The Coefficient of Area Use (CAU) both in total and per sampling season in each cell was calculated, using the following equation:

$$
C A U=\frac{D i}{T}
$$

where $D_{i}$ is the cumulative time spent following dolphins in cell $i$ and $T$ is the total time spent following dolphins during the sampling period (Karczmarski et al., 2000). Subsequently, the values of each cell per season were compared by means of a Wilcoxon test. Finally, with the purpose of spatially representing the habitat use, the values of the Coefficient of Use were grouped into three levels, low (0.002-0.006) medium (0.007-0.015) and high (0.016-0.025).

Univariate Chi-square analysis $\left(\chi^{2}\right)$ was applied to determine whether the groups used the area homogeneously with respect to the abiotic variables (depth, slope and distance to the coast) which were analysed in each cell (Zar, 1996). For this analysis, we started from the null hypothesis and the categories of environmental variables had an equal probability of occurrence. Additionally, a Multiple Correspondence Analysis (MCA) was used to determine if the habitat preferences (considering the variables depth, distance to the coast and slope) were related to group size and composition. For this analysis, the environmental variables were converted into categorical ordinal variables and, as a result of the test, a perceptual map was obtained for where the association between the set of categorical variables analysed were observed (Hair et al., 1999).

Logistic Regression analysis was used to predict the relationship between the environmental variables (depth, distance to the coast, and slope) and the presence or absence of the species (Hair et al., 1999). The method used during the logistic regression was 'stepwise backward', which included all the variables at the beginning and eliminated, in each step, those that contributed least to the significance of the model. The elimination of the 
variables was based on the probability of the Wald test. This test allows a chi-square test to contrast the null hypothesis that the coefficient of each variable is independent of zero. Finally, the result was validated with the Hosmer-Lemeshow goodness of fit test.

The proportion of time that the groups spent displaying a particular behaviour within the areas were estimated. A $\chi^{2}$ test was applied to determine if there was independence between behaviour and season, group size, and composition (Sokal and Rohlf, 1995). A Kruskal-Wallis test was applied to determine if there were differences between the behaviours in relation to the environmental variables. All statistical analyses were performed with SPSS software (version 19.0). Finally, maps were generated in order to visualise the areas used while displaying behaviour using a Geographic Information System.

\section{RESULTS}

\section{Habitat use}

From October 2009 to September 2010, 70 opportunistic surveys were conducted, and 86 groups of dolphins were observed. Total effort in the field was 310 hours, of which 44 hours were spent observing dolphins. Sampling effort in each season was equal to 155 hours. Out of the 250 cells analysed, dolphins were sighted in 140 (56\%) equating to an area of $36 \mathrm{~km}^{2}$. Use by dolphins was not evenly distributed over the study area. Tigrillo inlet and the waters northeast of the Caracas islands were the areas most used by dolphins, exhibiting a high to medium CAU. Common dolphins were not observed to use Mochima Bay during the assessment period (Fig. 2).

During the rainy season, dolphins used 120 cells corresponding to $30 \mathrm{~km}^{2}$ (Fig. 3a). During this time, dolphins were observed more intensively in the northeast and southeast of the Caracas islands. On the other hand, in the dry season, dolphins used 85 cells equivalent to $21 \mathrm{~km}^{2}$ with a tendency to use Tigrillo inlet and the Manare peninsula more intensively (Fig. 3b). Even though during the dry season dolphins used fewer areas, a Wilcoxon test found no statistical significance in habitat use between seasons $(z=1.69, p=0.09)$. The analysis of $\chi^{2}$ revealed that common dolphins use their habitat differentially, showing increased usage in zones with depths between 10 and $100 \mathrm{~m}\left(\chi^{2}=188.52, \mathrm{gl}=5, \mathrm{p}=0.00\right.$ ) (Fig. 4a), near the coast (less than $2 \mathrm{~km}, \chi^{2}=208.74, \mathrm{gl}=3, \mathrm{p}=0.00$ ) (Fig. 4b) and with low slope $\left(<0.09 \mathrm{~m} / \mathrm{km}, \chi^{2}=204.35, \mathrm{gl}=2, \mathrm{p}=0.00\right)$ (Fig. 4c).

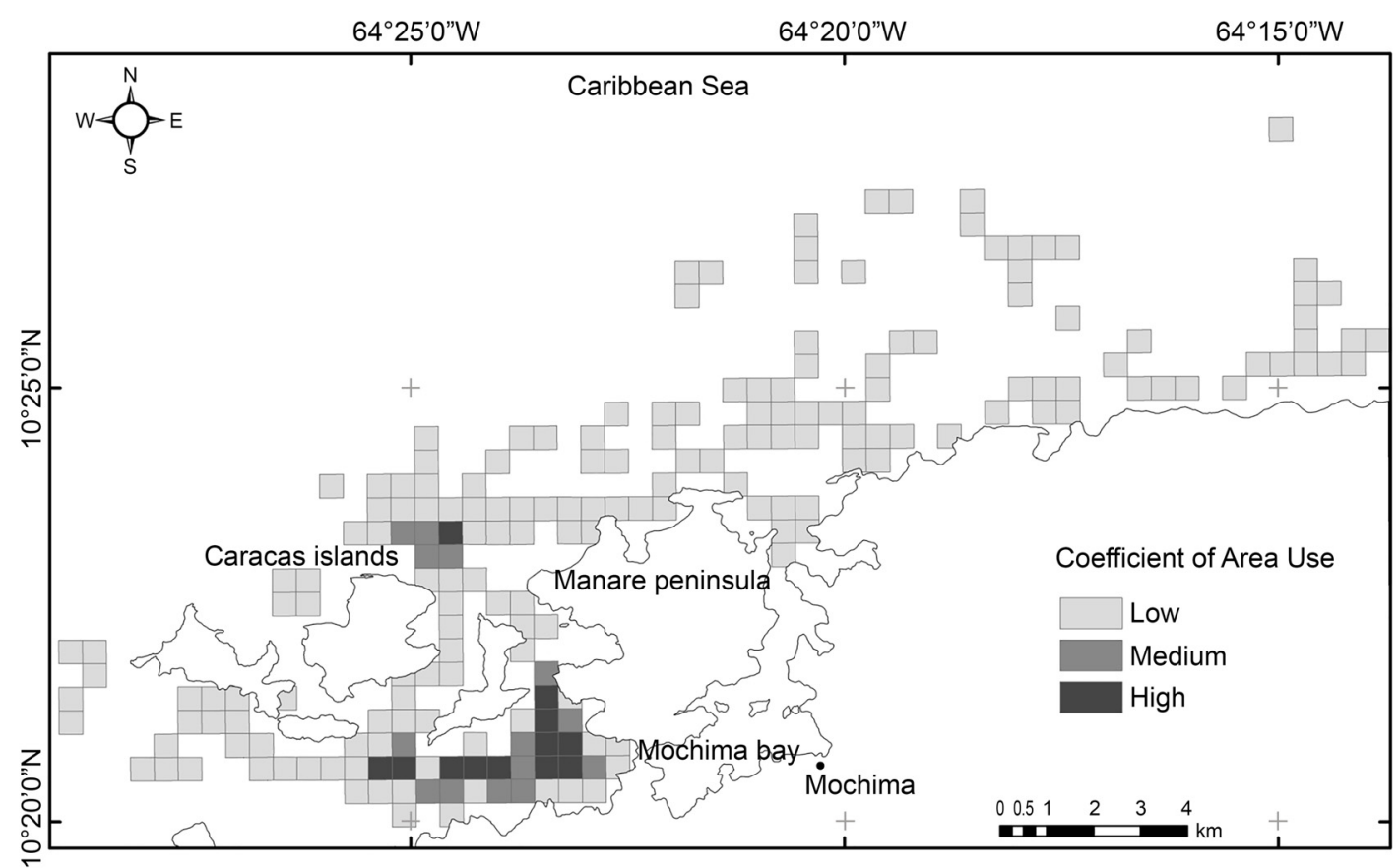

Fig. 2. Study area subdivided in cells of $500 \mathrm{~m} \times 500 \mathrm{~m}$. Each cell was characterised by a coefficient of area use (see text). 


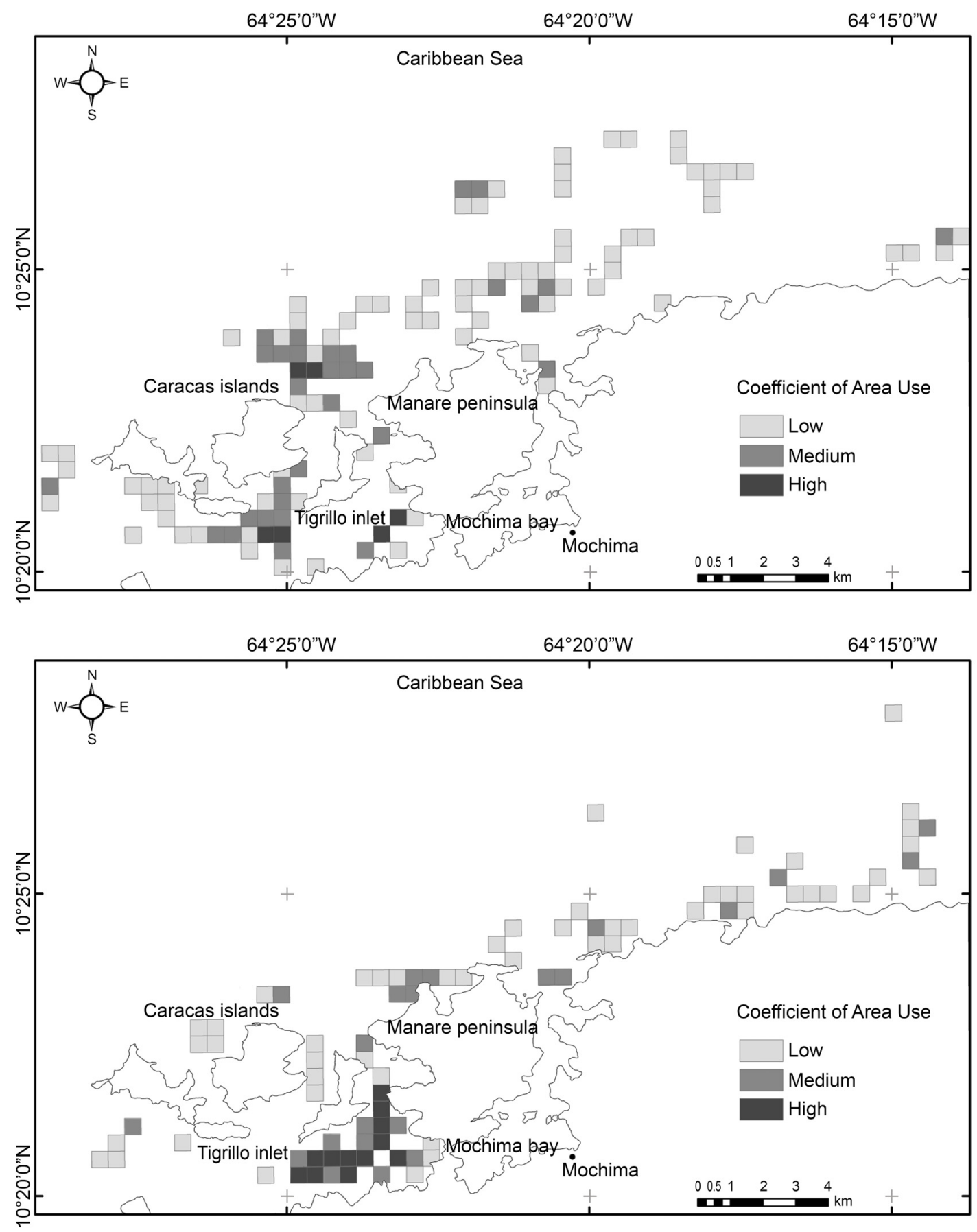

Fig. 3. Map of coefficient of area use by season, (a) rainy season (b) dry season.

Habitat use varied by group size and composition (Fig. 5). Groups of less than 20 individuals of adult-juvenile, mothers with calves and juveniles were observed using areas close to the coast (within $2 \mathrm{~km}$ ), with depths below $100 \mathrm{~m}$ and a low slope $(0.09 \mathrm{~m} / \mathrm{km})$. Mixed groups larger than 20 individuals, in addition to using nearshore areas, also used offshore areas (up to $5 \mathrm{~km}$ ). The variance explained by this analysis was $69.75 \%$.

\section{Presence/absence analysis}

The presence of common dolphins was analysed in relation to depth, slope and distance to the coast. Of the three variables analysed, depth and distance to the coast were significant with a negative beta coefficient, the probability of presence decreased with an increase in depth and distance to the coast. The correct classification rate of the model was $87.6 \%$. The level of significance of the Hosmer-Lemeshow test indicated that the calculated model was effectively adjusted to the data used to estimate it (Table 1). 

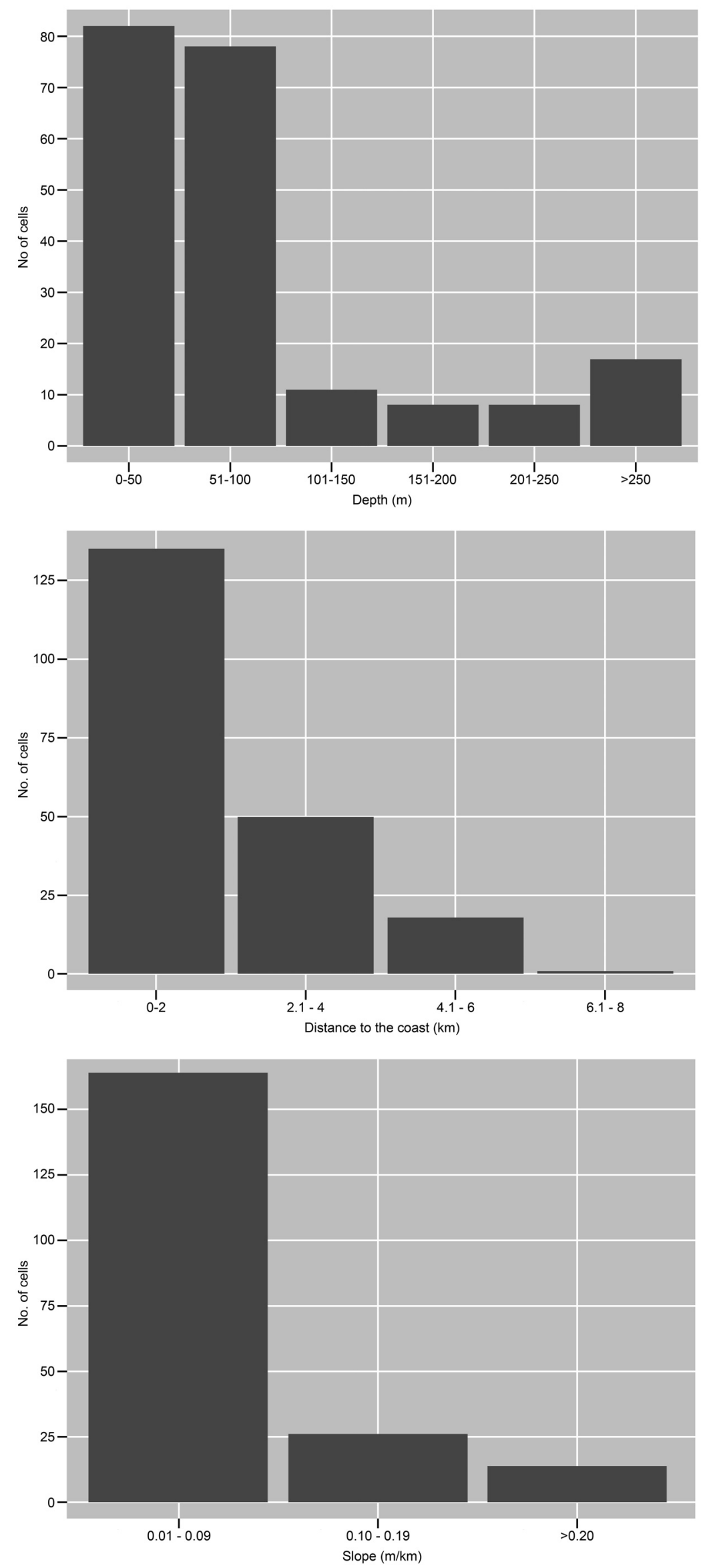

Fig. 4. Number of cells used by dolphins in each variable class, (a) depth (b) distance to the coast (c) slope. 


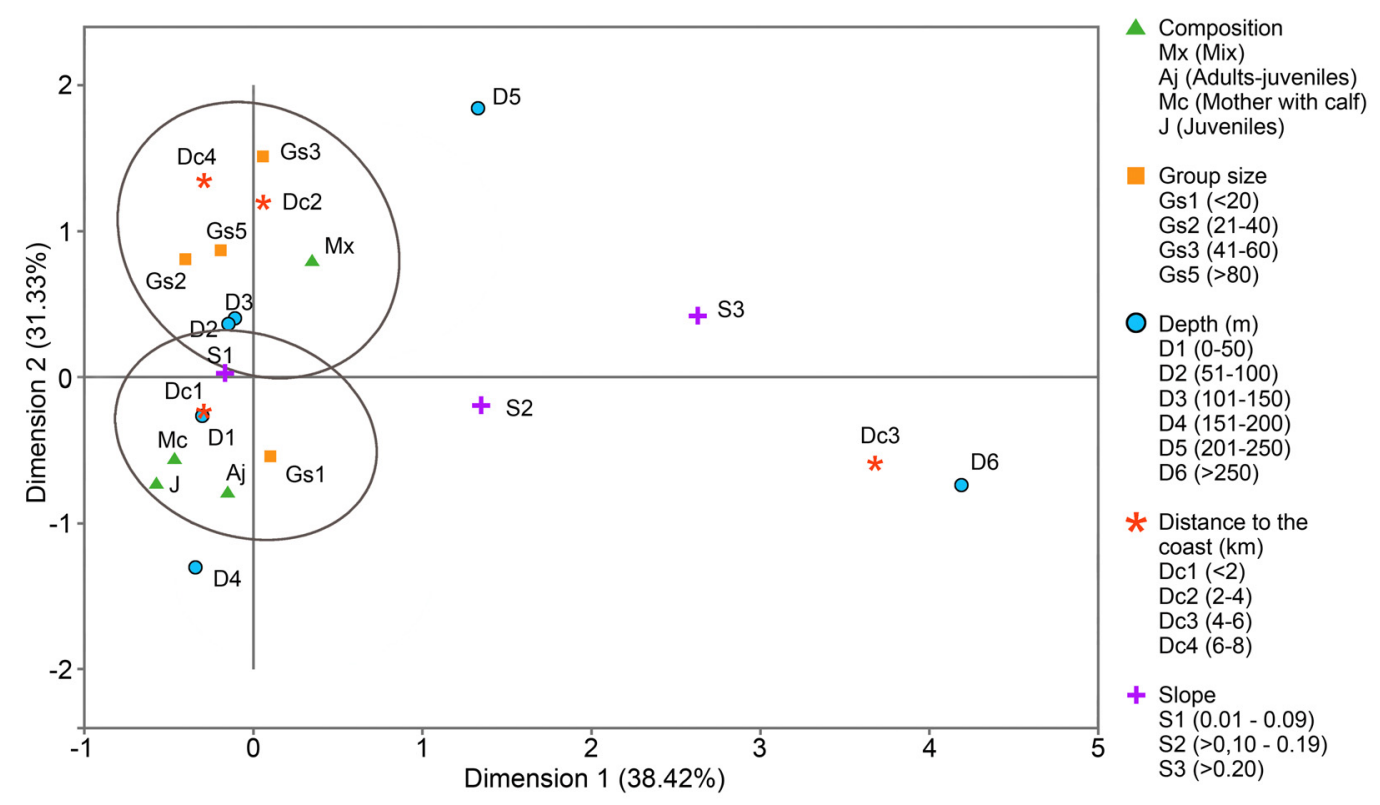

Fig. 5. Habitat use by group size and composition.

Table 1

Parameters for estimating the logistic regression model of the common dolphin as a function of the physical variables (depth, distance to the coast and slope) of the habitat.

\begin{tabular}{ccccccccc}
\hline & Variables & B & S.E. & Wald & df & Sig. & Exp(B) & $\begin{array}{c}\text { Hosmer- } \\
\text { Lemeshow test }\end{array}$ \\
\hline Step 1 & Depth & -0.131 & 0.021 & 40.133 & 1 & 0.000 & 0.877 & 0.920 \\
& $\begin{array}{c}\text { Distance from } \\
\text { the coast }\end{array}$ & -0.566 & 0.229 & 6.097 & 1 & 0.014 & 0.568 \\
\cline { 2 - 7 } & Slope & -4.684 & 6.732 & 0.484 & 1 & 0.487 & 0.009 \\
\hline Step 2 & Depth & -0.129 & 0.020 & 40.119 & 1 & 0.000 & 0.879 & 0.682 \\
& $\begin{array}{c}\text { Distance from } \\
\text { the coast }\end{array}$ & -0.571 & 0.228 & 6.246 & 1 & 0.012 & 0.565 \\
\hline
\end{tabular}

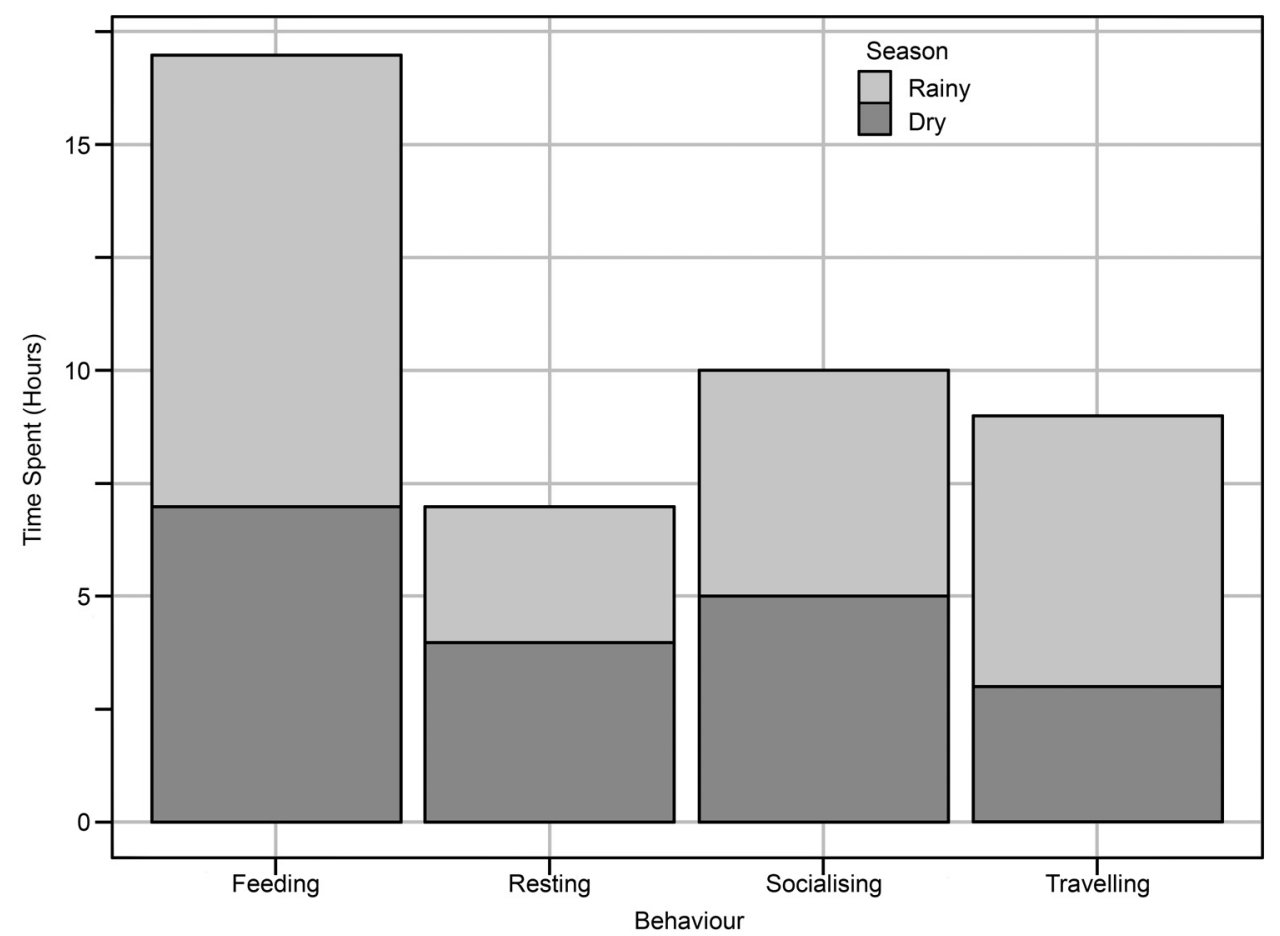

Fig. 6. Time spent on each behaviour by seasons. 


\section{Behaviour}

The behaviour most frequently observed was feeding ( $40 \%, n=18$ hours), followed by socialising ( $24 \%, n=11$ hours). Travelling was the third most frequent ( $19 \%, n=8$ hours) and resting was rarely seen $(17 \%, n=7$ hours). Dolphins spent more time feeding and travelling in the rainy season, but more time in feeding and socialising during the dry season (Fig. 6). Differences in behaviours in relation to season were found to be significant $\left(\chi^{2}=30.44, d f=3, p=0.001\right)$.

Feeding and travelling behaviours were observed throughout the study area, but more commonly to the northeast and southeast of the Caracas islands (Fig. 7a). Areas used included all categories of depth, distance to the coast and slope, nevertheless, dolphins spent more time in shallow areas near the coast (Fig. 8a-c).

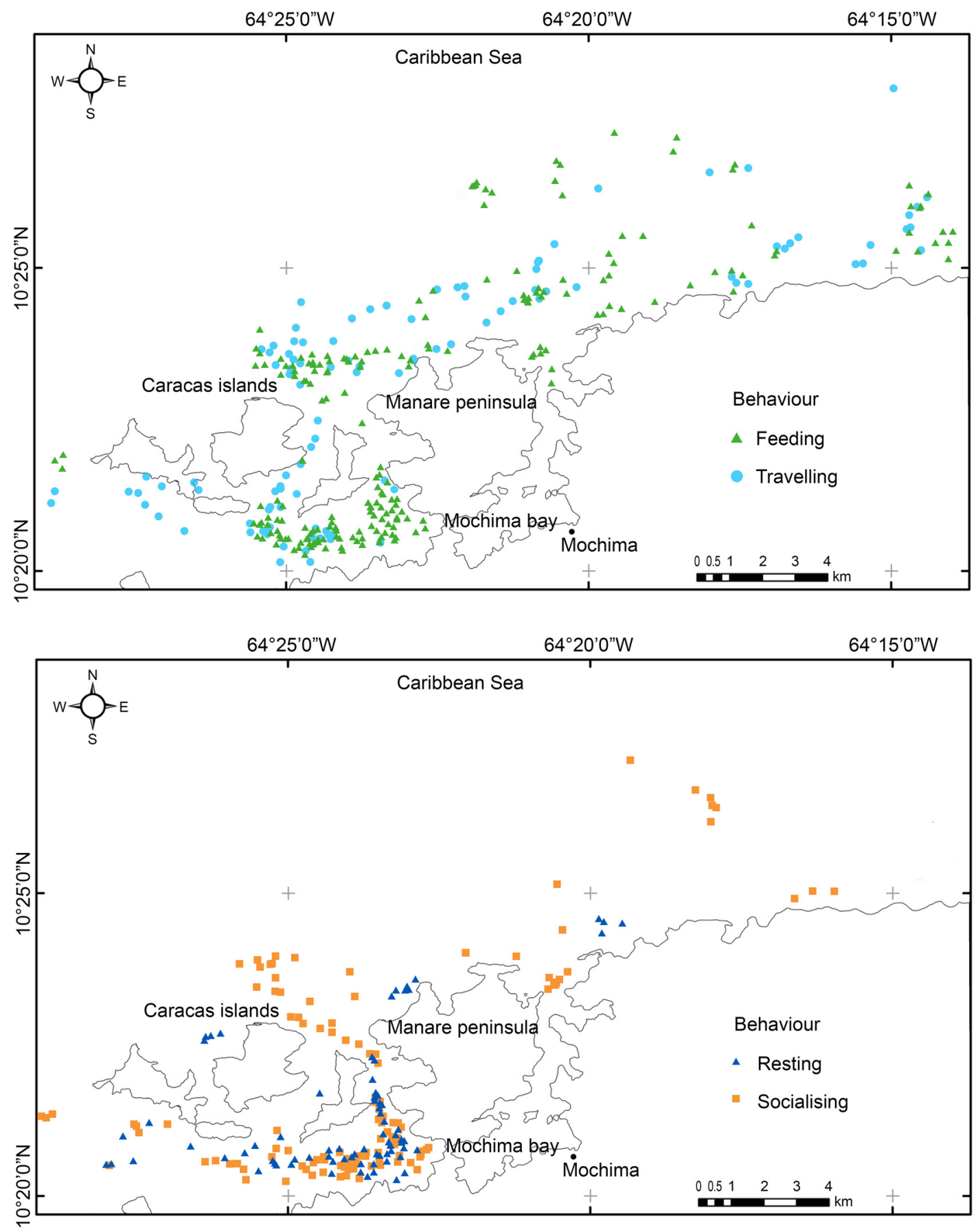

Fig. 7. Spatial distribution of behaviours observed in the common dolphin (Delphinus sp.) in the Mochima National Park, (a) feeding and travelling (b) resting and socialising. 

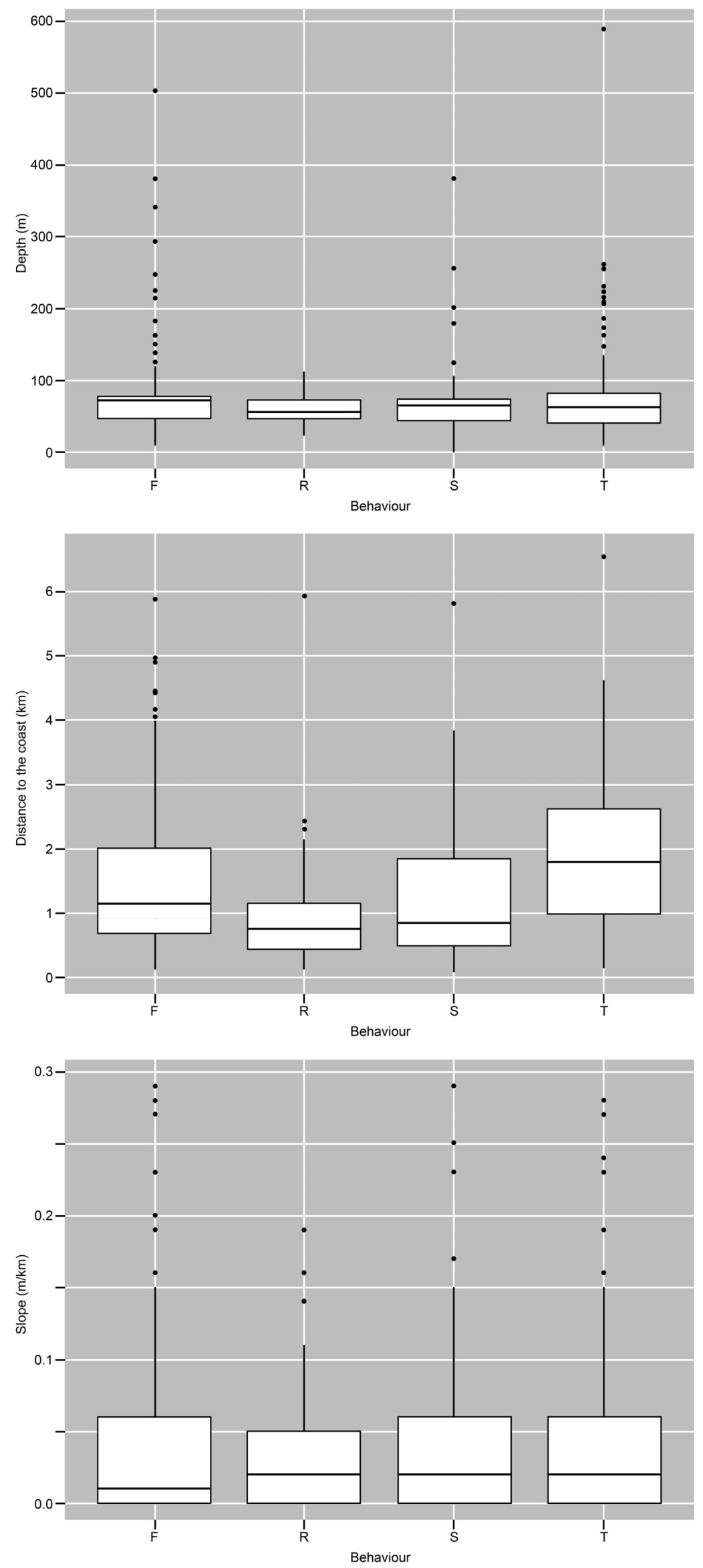

Fig. 8. Mean depth, distance to the coast and slope for common dolphins' behaviours, (a) depth (b) distance to the coast (c) slope. 
The dolphins were found to socialise and rest mostly in shallow nearshore waters (Fig. 7b, 8a-c). These behaviours were mainly observed in Tigrillo inlet, the Manare peninsula and the Caracas islands. Behaviours varied significantly with the distance to the coast $(H=44.03, d f=3, p=0.004)$ and depth $(H=8, d f=3, p=0.03)$, however the slope was found to be not significant $(H=1.46, d f=3, p=0.69)$.

The time that was spent displaying was found to vary significantly among group types $\left(\chi^{2}=37.09, \mathrm{df}=9\right.$, $\mathrm{P}=0.001$ ). Mixed and adults-juvenile groups spent a greater proportion of time feeding (Fig. 9a). Mothers with calves spent more time socialising and resting. Juveniles were more often feeding and travelling. All behaviours monitored also varied with group size (Fig. 9b), the smaller groups (1-20 individuals) spent more time feeding and socialising and larger groups (more than 80 individuals) spending more time feeding $\left(\chi^{2}=78.42, \mathrm{df}=9\right.$, $p=0.001)$.

\section{DISCUSSION}

This study provides new information on the ecology of the common dolphin (Delphinus sp.), one of the most commonly sighted cetaceans in the eastern region of Venezuela. Specifically, it reports new insights on habitat use, behaviour and occurrence of common dolphins for the Mochima National Park, a protected area that in recent years has had a high pressure by fisheries, chemical and acoustic pollution, commercial shipping traffic and unregulated dolphin watching activities (Bolaños-Jimenez, et al., 2007; Oviedo, 2008; Jefferson et al., 2009; Alvarez, 2015).

Common dolphins show differential use of the area. During the rainy season, dolphins were sighted to the northeast and southeast of Caracas islands while sightings were more common within Tigrillo inlet and Manare peninsula in the dry season. This result could be attributed to seasonal variations in the food resource (Wilson et al., 1997; Martinez-Serrano et al., 2011). The only known quantitative data on the diet of this population, determined by stomach contents, suggested that Venezuelan common dolphin feed mainly on Spanish sardine (Sardinella aurita; Naveira, 1996). These mesopelagic species have seasonal variations associated with coastal upwelling in the dry season (Mendoza et al., 1998; Gonzalez et al., 2007; Rueda et al., 2017,). During the dry season, sardines are abundant near the coast. Once the dry season is over, adult sardines move towards the northeast of our study area (Freón et al., 1997).

The sardine's movement towards the northeastern side of the study area coincides with the pattern of habitat use observed in this study. These results match those observed in an earlier study by Oviedo et al. (2010), which was conducted in the western area of the park, which also recorded seasonal and spatial variations in the habitat use by common dolphins. The authors suggested that variations were attributed to local movements of dolphin groups between feeding areas and this study supports their hypothesis.

The Tigrillo inlet and the waters northeast of the Caracas islands were the areas most frequently used by the observed dolphins. Dolphins were never observed in Mochima Bay where there is a significant amount of daily vessel traffic. In 2010, 90 boats were registered in this bay (INPARQUES, 2010) which may be a possible reason for the absence of dolphins. We detected changes in the behaviour of groups of mothers with calves and juveniles when two or more boats were close to them. Although these results were not the focus of this study, it is an important finding and could be considered a topic for future research. In coastal marine environments, vessel traffic is the anthropogenic activity with the greatest potential to disturb marine wildlife (Bejder, 2005; Bejder et al., 2006b; Lusseau et al., 2006; Lundquist, 2011). Previous research (Meissner et al., 2015) has indicated that commercial tourism and recreational vessels have a negative impact on the behaviour of common dolphins.

In general, common dolphins used shallow inshore waters more intensively, but this habitat use varied depending on group size and composition. Small groups composed of adult-juvenile, mothers with calves and juveniles mainly used shallow and nearshore areas. Larger groups of mixed composition were observed in both shallow and deep waters. Similar results have been shown elsewhere in common dolphins (Stockin et al., 2008; Filby, et al., 2010; Oviedo et al., 2010; Gaborit-Haverkort, 2012; Bilgmann et al., 2018) and other dolphin species (Sayman et al., 1973; Shane et al., 1986; Würsig, 1986; Garaffo et al., 2007; Gowans et al., 2008).

Some authors have speculated that using shallow nearshore areas would provide protection from predators (Würsig and Würsig, 1979; Norris and Dohl, 1980a), especially for mothers with calves and juvenile groups (Mann 

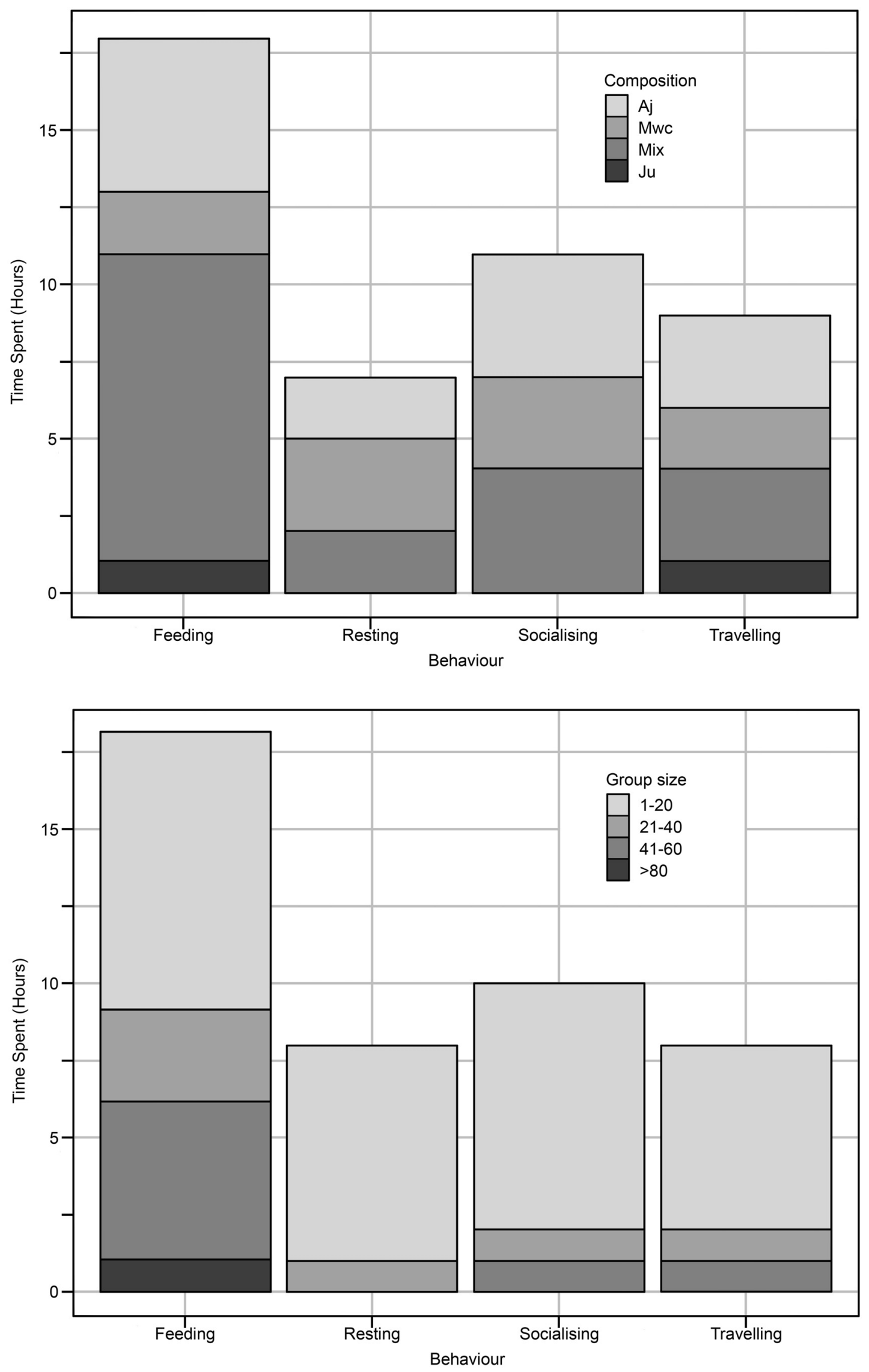

Fig. 9. Time spent on each behaviour by composition (a) and group size (b). 
and Barnett, 1999). Likewise, being in a larger group reduces the risk of predation (Clutton-Brock et al., 1999; Hebblewhite and Pletscher, 2002). Saayman et al. (1972) pointed out that in deep waters the only defence against predators is the formation of large groups.

It is probable that predation risk may be another factor influencing observed habitat use in our study area (van Schaik and van Hoff, 1983; Lima and Dill, 1990; Heithaus and Dill, 2006; Stockin et al., 2008). During the study, we did not observe any predators in the area, although their presence was highlighted by local fishermen during informal interviews. Several authors (Jefferson et al., 1991; Visser, 1999; Maldini, 2003; Celona et al., 2006; Santos et al., 2006) have documented attacks on small odontocetes. In Venezuela, Sánchez-Criollo and Bermúdez-Villapol (2011), assessed shark attack rates on four species of cetaceans stranded in Margarita Island. Three species were identified as responsible for most cetacean attacks: cookiecutter sharks (Genus Isistius); tiger sharks (Galeocerdo cuvieri); and mako sharks (Isurus spp.). The results of that study indicated that shark attack rates were higher on common dolphins (Delphinus sp.) than on other species. This supports the hypothesis that mothers with calves and juveniles spend more time in shallower waters as a protection strategy (Degrati et al., 2008).

It was found that the behaviour of common dolphins in Mochima National Park was mostly influenced by season, depth, distance to the coast, group size, and group composition. The slope had no apparent influence on behaviour of common dolphins in this region. Feeding was the most frequent and widely observed behaviour over the entire study period. These results differ from Oviedo et al. (2010), Molero-Lizarraga et al. (2008) and Rangel and Cobarrubia (2008), who observed that travelling was the most frequent behaviour. Their studies were conducted in areas adjacent to the Mochima National Park. The results are however not directly comparable because the data collection methods were different. The differences observed among studies may be due to the daily and seasonal movements of prey. Food resources are rarely uniformly distributed throughout the environment, which requires travelling between foraging locations. According to Degrati et al. (2008) and Neumann and Orams (2005), there is a strong correlation between travelling and feeding. Travelling could therefore be directly related to the need to locate prey.

During our study travelling behaviour was generally preceded by feeding. Sequences of travelling and feeding have been observed previously (Degrati et al., 2008). Feeding was observed more frequently in larger groups than in smaller groups. These differences may occur because of the fission-fusion nature of common dolphin societies (Neumann, 2001), as groups merge to form larger groups for the purpose of foraging (Heithaus, 2001). Dolphins potentially feed in larger groups in the presence of large fish schools or when their prey are patchily distributed (Burgess, 2006).

Socialising was the second most observed behaviour. According to Neumann and Orams (2005) and Doenier et al. (1997) activities such as socialising should be more frequent, after satisfying nutritional needs. Socialising was recorded more frequently in both smaller groups, and groups of mothers with calves. Similar results have been described in other studies (Daura-Jorge et al., 2005; Garaffo et al., 2007; Stockin et al., 2009). The low frequency of resting behaviour observed in this study could be a sampling bias. When common dolphins rest, they show inconspicuous surface activity, making it very difficult to record this behaviour (Neumann and Orams, 2005). An alternative possibility is that the resting behaviour of the dolphins was disturbed by our boat. It was observed that while groups of mothers with calves spent more time in resting behaviours, these groups tended to be more sensitive to boat presence and noise (Guerra et al., 2014). Studies examining the effects of boats on cetaceans have quantified short-term changes in surface behaviour, frequently measured as changes in group activity (Lusseau 2003; Christiansen et al., 2010).

We identified priority habitats for feeding, refuge, and resting areas especially when observing mothers with calves and groups of juveniles. The use patterns presented here have important implications for park management. Current planning (especially zoning) may not be effective because it does not include dolphin protection areas. In recent years, human disturbances have affected Mochima National Park, so special legislation and control is needed. The purpose of this study was to provide data that would help the effective conservation of these dolphin populations and to present the evidence found. 


\section{Limitations}

These results need to be interpreted with caution. We identified a few possible sources of bias that could influence results. Firstly, data for this study were collected using platforms of opportunity meaning the spatial coverage was strictly limited by the pre-determined route. Despite this limitation, it provided an inexpensive way to conduct surveys on cetaceans (Hupman et al., 2015). Secondly, the dolphins were monitored for up to 30 minutes. This time limit was established to avoid the animals' habituation to the boat and for the continuity of the search for further groups. To mitigate these problems, sampling effort in each season was increased. Thirdly, the presence/absence data used in the logistic regression model could contain errors. It is possible that dolphins may have been present in an area but were not detected. According to Mackenzie (2005), observed absence may simply be the result of the survey method failing to detect the presence of the species that are resident at the location. While the presence of a target species can often be confirmed at a location, it is generally impossible to confirm species' absence. Finally, the sampling method was based on surface behaviours, this may have introduced bias because only more visible or conspicuous behaviours are recorded, and this would affect the observation of more subtle behaviours such as resting.

\section{ACKNOWLEDGEMENTS}

Special thanks go to Ruben Pennot, our boat operator. We also gratefully acknowledge the Instituto de Estudios Avanzados (IDEA) for logistical support, as well as both FONACIT and Cetacean Society International (CSI) for funding this project. Special thanks to Dr Pedro Borges (IVIC) for feedback on a draft of this manuscript, Rafael Puche for preparing most of the figures and Imogen Sawyer for assistance with English translation. Two anonymous reviewers gave useful comments on the manuscript. Research activities were conducted under authorisation from the Ministry of Environment of Venezuela and INPARQUES.

\section{REFERENCES}

Acevedo, R. 2007. Potential geographical distribution of seven species of marine cetaceans reported in Venezuela, Southeast Caribbean. Acta Zoologica Sinica 53(5): 853-64.

Altmann, J. 1974. Observational study of behavior: sampling methods. Behaviour 49: 227-67. [Available at: http://www.jstor.org/ stable/4533591].

Álvarez, R. 2015. Valoración económica ambiental del Parque Nacional Mochima de Venezuela. Doctoral Thesis, Universidad de Córdoba. 219pp. [In Spanish].

Au, D.W.K. and Perryman, W.L. 1985. Dolphin habitats in the eastern tropical Pacific. Fish. Bull. 83(4): 623-43.

Ballance, L.T. 1992. Habitat use patterns and ranges of the bottlenose dolphin in the Gulf of California, Mexico. Mar. Mamm. Sci. 8(3): 262-74. [Available at: $h$ ttps://doi.org/10.1111/j.1748-7692.1992.tb00408.x].

Bearzi, M. 2005. Habitat partitioning by three species of dolphins in Santa Monica Bay, California. Bull. S. Calif. Acad. Sci. 104(3): 113-24. [Available at: $h$ ttps://doi.org/10.3160/0038-3872(2005)104[113:HPBTSO]2.0.CO;2].

Bejder, L. 2005. Linking short and long-term effects of nature-based tourism on cetaceans. PhD Thesis, Dalhousie Univerity, Canada. 158pp. [Available at: $h$ ttp://hdl.handle.net/10222/54676].

Bejder, L., Samuels, A., Whitehead, H., Gales, N., Mann, J., Connor, R., Heithaus, M., Watson-Capps, J. and Flaherty, C. 2006. Decline in relative abundance of bottlenose dolphins exposed to long-term disturbance. Conserv. Biol. 20(6): 1,791-98. [Available at: https://doi.org/10.1111/j.1523-1739.2006.00540.x].

Bermúdez-Villapol, L. and Sayegh, A. 2007. Lista actualizada de cetáceos de la cuenca nororiental de Venezuela. Page 209. In: Libro de Resúmenes del VII Congreso Venezolano de Ecología, Ciudad Guayana, Venezuela.

Beyer, H.L., Haydon, D.T., Morales, J.M., Frair, J.L., Hebblewhite, M., Mitchell, M. and Matthiopoulos, J. 2010. The interpretation of habitat preference metrics under use-availability desians. Philos. Trans. R. Soc. Lon. 365: 2245-54. [Available at: https://doi.org/10.1098/ rstb.2010.0083].

Bilgmann, K., Parra, G. and Moller, L. 2018. Ocurrence, distribution and abundance ode cetaceans off the wetern Eyre Peninsula in the Great Autralian Bight. Deep Sea Res. Part II 157: 134-35. [Available at: https://doi.org/10.1016/j.dsr2.2017.11.006].

Bolaños-Jiménez, J., Herrera, O.L., Panza, R. and Villarroel-Marin, A. 2007. Preliminary assessment of marketing-related aspects on dolphinwatching in the Mochima National Park, northeastern Venezuela. Paper SC/59/WW19 presented to the IWC Scientific Committee, May 2007, Anchorage, USA (unpublished). 5pp. [Paper available from the Office of this Journal].

Burgess, E.A. 2006. Foraging ecology of common dolphins (Delphinus sp.) in the Hauraki Gulf, New Zealand. Masters thesis, Massey University, Auckland, New Zealand. 143pp. [Available at: $h t t p: / / h d l . h a n d l e . n e t / 10179 / 12535]$.

Cañadas, A., Sagarminaga, R. and García-Tiscar, S. 2002. Cetacean distribution related with depth and slope in the Mediterranean waters off southern Spain. Deep-Sea Res. I 49(11): 2053-73. [Available at: https://doi.org/10.1016/S0967-0637(02)00123-1].

Celona, A., De Maddalena, A. and Comparetto, G. 2006. Evidence of predatory attack on bottlenose dolphin Tursiops truncatus by a great white shark Carcharodon carcharias in the mediterranean sea. Ann. Ser. Hist. Nat. (Koper) 35: 149-64. 
Christiansen, F., Lusseau, D., Stensland, E. and Berggren, P. 2010. Effects of tourist boats on the behaviour of Indo-Pacific bottlenose dolphins off the south coast of Zanzibar. Endanger. Species Res. 11(1): 91-99. [Available at: https://doi.org/10.3354/esr00265].

Clutton-Brock, T.H., Gaynor, D., Mcllrath, G.M., Maccoll, A.D.C., Kansky, R., Chadwick, P., Manser, M., Skinner, J.D. and Brotherton, P.N.M. 1999. Predation, group size and mortality in a cooperative mongoose, Suricata suricatta. J. Anim. Ecol. 68(4): 672-83. [Available at: https://doi.org/10.1046/j.1365-2656.1999.00317.x].

Collet, A. and Saint Girons, H. 1984. Preliminary study of the male reproductive cycle in common dolphins, (Delphinus delphis), in the eastern North Atlantic. Rep. Int. Whal. Comm. (special issue) 6: 355-60.

Committee on Taxonomy. 2019. List of marine mammal species and subspecies. Society for Marine Mammalogy. [Available at: www.marinemammalscience.org, accessed on 15 March 2020].

Daura-Jorge, F.G., Wedekin, L.L., Piacentini, V.D.Q. and Simões-Lopes, P.C. 2005. Seasonal and daily patterns of group size, cohesion and activity of the estuarine dolphin, Sotalia guianensis (P.J. van Bénéden) (Cetacea, Delphinidae), in southern Brazil. Rev. Bras. Zool 22(4): 1014-21. [Available at: $h$ ttps://doi.org/10.1590/S0101-81752005000400029].

Dawson, S.M. and Slooten, E. 1993. Conservation of Hector's dolphins: The case and process which led to the establishment of the Banks Peninsula Marine Mammal Sanctuary. Aquat. Conserv. 3(3): 207-21. [Available at: https://doi.org/10.1002/aqc.3270030305].

Degrati, M., Dans, S., Pedraza, S., Crespo, E. and Garaffo, G. 2008. Diurnal behavior of Dusky dolphins, Lagenorhynchus obscurus, in Golfo Nuevo, Argentina. J. Mammal. 89(5): 1241-47. [Available at: https://doi.org/10.1644/07-MAMM-A-110.1].

Doenier, P.B., Delgiudice, G.D. and Riggs, M.R. 1997. Effects of winter supplemental feeding on browse consumption by white-tailed deer. Wildl. Soc. Bull. 25(2): 235-43.

Esteves, M.A. and Oviedo, L. 2007. A potential morphotype of common dolphin (Delphinus spp.) on the northeast coast of Venezuela. Aquat. Mamm. 33: 229-34. [Available at: $h$ ttps://doi.org/10.1578/AM.33.2.2007.229].

Evans, W.E. 1994. Common dolphin, white-bellied porpoise - Delphinus delphis Linnaeus, 1758. pp.191-224. In: S.H. Ridgway and R. Harrison (eds). The First Book of Dolphins. Academic Press, London and San Diego. 416pp.

Ferrero, R.C. and Walker, W.A. 1995. Growth and reproduction of the common dolphin, Delphinus delphis Linnaeus, in the offshore waters of the north Pacific Ocean. Fish. Bull. 93(3): 483-94.

Fertl, D. 1994. Occurrence patterns and behavior of bottlenose dolphins (Tursiops truncatus) in the Galveston ship channel, Texas. Tex. J. Sci 46(4): 299-317.

Filby, N., Bossley, M., Sanderson, K., Martinez, E. and Stockin, K. 2010. Distribution and population demographics of common dolphins (Delphinus delphis) in the Gulf of St Vincent, South Australia. Aquat. Mamm. 36(1): 33-45.

Fischhoff, I.R., Sundaresan, S.R., Cordingley, J. and Rubenstein, D.I. 2007. Habitat use and movements of plains zebra (Equus burchelli) in response to predation danger from lions. Behav. Ecol. 18(4): 725-29. [Available at: https://doi.org/10.1093/beheco/arm036].

Freón, P., El Khattabi, M., Mendoza, J. and Guzmán, R. 1997. Unexpected reproductive strategy of Sardinella aurita of the coast of Venezuela. Mar. Biol. 128: 363-72.

Gaborit-Haverkort, T. 2012. The occurrence and habitat use of common dolphins (Delphinus sp.) in the central Bay of Plenty. MSc Thesis, Massey University, New Zealand. 150pp. [Available at: https://mro.massey.ac.nz/handle/10179/3871]

Garaffo, G.V., Dans, S.L., Pedraza, S.N., Crespo, E.A. and Degrati, M. 2007. Habitat use by dusky dolphin in patagonia: How predictable is their location?. Mar. Biol. 152: 165-77. [Available at: https://doi.org/10.1007/s00227-007-0686-0].

Gaskin, D.E. 1968. Distribution of Delphinidae (Cetacea) in relation to sea surface temperatures off eastern and southern New Zealand. New Zeal. J. Mar. Fresh. Res. 2(3): 527-34.

González, L.W., Eslava, N. and Gómez, E. 2007. Parámetros poblacionales de la sardina (Sardinella aurita) del sureste de la Isla de Margarita. Bol. Centr. Invest. Biol. 41(4): 457-70.

Gowans, S., Würsig, B. and Karczmarski, L. 2008. The social structure and strategies of Delphinids: Predictions based on an ecological framework. Adv. Mar. Biol. 53: 195-294. [Available at: $h$ ttps://doi.org/10.1016/S0065-2881(07)53003-8].

Guerra, M.G., Dawson, S.M., Brough, T.E. and Rayment, W.J. 2014. Effects of boats on the surface and acoustic behaviour of an endangered population of bottlenose dolphins. Endanger. Species Res. 24: 221-36. [Available at: https://doi.org/10.3354/esr00598].

Hair, J.F., Anderson, R.E., Tatham, R.L. and Black, W.C. 1999. Análisis Multivariante. Pearson, Madrid, España. 832pp.

Hastie, G.D. 2003. Distribution of small cetaceans within a candidate Special Area of Conservation; implications for management. J. Cetacean Res. Manage. 5(3): 261-66.

Hebblewhite, M. and Pletscher, D.H. 2002. Effects of elk group size on predation by wolves. Can. J. Zool. 80(5): 800-09. [Available at: https://doi.org/10.1139/z02-059].

Heithaus, M.R. 2001. Predator-prey and competitive interactions between sharks (order Selachii) and dolphins (suborder Odontoceti): A review. J. Zool. 253: 53-68. [Available at: https://doi.org/10.1017/S0952836901000061].

Heithaus, M.R. and Dill, L.M. 2006. Does tiger shark predation risk influence foraging habitat use by bottlenose dolphins at multiple spatial scales. Oikos 114(2): 257-64. [Available at: https://doi.org/10.1111/j.2006.0030-1299.14443.x].

Hooker, S.K., Whitehead, H. and Gowans, S. 1999. Marine protected area design and the spatial and temporal distribution of cetaceans in a submarine canyon. Conserv. Biol. 13(3): 592-602.

Hui, C. 1987. Power and speed of swimming dolphins. J. Mammal. 68(1): 126-32.

Hui, C.A. 1979. Undersea topography and distribution of dolphins of the genus Delphinus in the Southern California Bight. J. Mammal. 60(3): 521-27.

Hupman, K., Visser, I., Martinez, E. and Stockin, K. 2015. Using platforms of opportunity to determine the occurrence and group characteristics of orca (Orcinus orca) in the Hauraki Gulf, New Zealand. New Zeal. J. Mar. Freshw.r Res. 49(1): 132-49. [Available at: https://doi.org/10.1080/00288330.2014.980278].

INPARQUES. 2010. Registro de navegación y circulación por Mochima, Instituto Nacional de Parques. Ministerio del Poder Popular para Ecosocialismo y Aguas. [Available from the author]. 
Jefferson, T.A., Fertl, D., Bolaños-Jiménez, J. and Zerbini, A. 2009. Distribution of common dolphins (Delphinus sp.) in the western Atlantic Ocean: a critical re-examination. Mar. Biol. 156: 1109-24.

Jefferson, T.A., Stacey, P.J. and Baird, R.W. 1991. A review of killer whale interactions with other marine mammals: predation to coexistence. Mamm. Rev. 21(4): 151-80. [Available at: https://doi.org/10.1111/j.1365-2907.1991.tb00291.x].

Johnson, G. 2000. Spatial Ecology of the Eastern Massasauga (Sistrurus c. catenatus) in a New York Peatland. J. Herpetol. 34(2): 186-92. [Available at: $h$ ttps://doi.org/10.2307/1565414].

Karczmarski, L., Cockcroft, V.G. and McLachlan, A. 2000. Habitat use and preferences of Indo-Pacific humpback dolphins Sousa chinensis in Algoa Bay, South Africa. Mar. Mamm. Sci. 16(1): 65-79. [Available at: https://doi.org/10.1111/j.1748-7692.2000.tb00904.x].

Kofoky, A., Andriafidison, D., Ratrimomanarivo, F., Razafimanahaka, H.J., Rakotondravony, D., Racey, P.A. and Jenkins, R.K.B. 2007. Habitat use, roost selection and conservation of bats in Tsingy de Bemaraha National Park, Madagascar. Biodivers. Conserv. 16(4): 1039-53. [Available at: $h$ ttp://dx.doi.org/10.1007/s10531-006-9059-0].

Krausman, P.R. 1999. Some basic principles of habitat use. pp.85-90. In: Launchbaugh, K.L., Sanders, K.D. and Mosley, J.L. (eds). Grazing Behaviour of Livestock and Wildlife, Idaho Forest, Wildlife and Range. University of Idaho, Moscow.

Lima, S.L. and Dill, L.M. 1990. Behavioral decisions made under the risk of predation: a review and prospectus. Can. J. Zool. 68(4): 61940.

Linares, M.A. 2016. Evaluación de CD, CR, CU, HG, NI, PB Y ZN en el Parque Nacional Mochima e Isla la Tortuga, Venezuela, empleando Abudefduf Saxatilis como Biomonitor. BSc Thesis, Universidad central de Venezuela. 99pp. [In Spanish]. [Available at: http://saber. ucv.ve/handle/123456789/13314].

Lundquist, D.J. 2001. Behaviour and movement patterns of dusky dolphins (Lagenorhynchus obscurus) off Kaikoura, New Zealand: Effects of tourism. PhD Thesis, University of Otago. 156pp. [Available at: $h$ ttp://hdl.handle.net/10523/2125].

Lusseau, D. 2003. Male and female bottlenose dolphins Tursiops sp. have different strategies to avoid interactions with tour boats in Doubtful Sound, New Zealand. Mar. Ecol. Prog. Ser. 257: 267-74. [Available at: https://doi.org/10.3354/meps257267].

Lusseau, D. 2005. Residency pattern of bottlenose dolphin (Tursiops sp.) in Milford Sound, New Zealand, is related to boat traffic. Mar. Ecol. Prog. Ser. 295: 265-72. [Available at: https://doi.org/10.3354/meps295265].

Lusseau, D., Slooten, E. and Currey, R. 2006. Unsustainable dolphin watching activities in Fiordland, New Zealand. Tour. Mar. environ. 3(2): 173-78. [Available at: $h t t p s: / / d o i . o r g / 10.3727 / 154427306779435184]$.

MacKenzie, D.I. 2005. What are the issues with presence-absence data for wildlife managers. J.f Wildl. Manag. 69: 849-60. [Available at: https://doi.org/10.2193/0022-541X(2005)069[0849:WATIWP]2.0.CO;2].

Maldini, D. 2003. Evidence of predation by a tiger shark (Galeocerdo cuvier) on a spotted dolphin (Stenella attenuata) off O'ahu, Hawai. Aquat. Mamm. 29(1): 84-7. [Available at: https://doi.org/10.1578/016754203101023915].

Manly, B.F.J., McDonald, L.L., Thomas, D.L., McDonald, T.L. and Erickson, W.P. 2002. Resource Selection by Animals: Statistical Design and Analysis. 1 ed. Springer, Dordrecht. 177pp.

Mann, J. 1999. Behavioural sampling methods for cetaceans: A review and critique. Mar. Mamm. Sci. 15(1): 102-22. [Available at: https://doi.org/10.1111/j.1748-7692.1999.tb00784.x].

Mann, J. and Barnett, H. 1999. Lethal tiger shark (Galeocerdo cuvier) attack on bottlenose dolphin (Tursiops sp.) calf: defense and reactions by the mother. Mar. Mamm. Sci. 15(2): 568-75. [Available at: https://doi.org/10.1111/j.1748-7692.1999.tb00823.x].

Mann, J., Connor, R.C., Barre, L.M. and Heithaus, M.R. 2000. Female reproductive success in bottlenose dolphins (Tursiops $s p$.): Life history, habitat, provisioning and group-size effects. Behav. Ecol. 11: 210-19. [Available at: https://doi.org/10.1093/beheco/11.2.210].

Martínez-Serrano, I., Serrano, A., Heckel, G. and Schramm, Y. 2011. Distribution and home range of bottlenose dolphins (Tursiops truncatus) off Veracruz, Mexico. Cienc. Mar. 34(7): 379-92. [Available at: https://doi.org/10.7773/cm.v37i4A.1860].

Mendoza, J.P., Freon, P., Guzmán, R. and Aparicio, R. 1998. Sardinella aurita population dynamics related to environmental parameters in the Southern Caribbean (Venezuela). pp.239-309. In: M. Durand, P. Cury, R. Mendelssohn., C. Roy, A. Bakun and D. Pauly (eds). Global Versus Local Changes in Upwelling Systems. Collection colloques et seminaries, ORSTOM, Paris, France.

Miloslavich, P., Klein, E., Yerena, E. and Martin, A. 2003. Marine biodiversity in Venezuela: status and perspectives. Gayana 67(2): 275301. [Available at: $h t t p: / / d x . d o i . o r g / 10.4067 /$ S0717-65382003000200012].

Miro, O.M. 1974. Morfología submarina y sedimentos marinos recientes del margen continental del nororiente de Venezuela. Paper presented at III Conferencia de las Naciones Unidas sobre derechos del mar. 230pp. [Available from the author].

Molero-Lizarraga, A., Hernández, J. and Bermúdez, L. 2008. Patrones de comportamiento del delfín común de hocico largo (Delphinus capensis, Gray 1828) en la ruta marítima Isla de Margarita-Cumana, Cuenca Oriental de Venezuela, 2003-2004. Paper presented at XIII Reunión de Trabajo de Especialistas de Mamíferos Marinos de América del Sur, 7mo Congreso SOLAMAC, Montevideo, Uruguay, Octubre 2008.

Molero, A. 2005. Distribución y abundancia relativa de cetáceos en la ruta marítima Isla de Margarita-Cumaná. BSc Thesis, Universidad del Zulia. 60pp. [In Spanish].

Naveira, J.L. 1996. El Orden Cetacea en la región nororiental de Venezuela, Instituto Oceanográfico de Venezuela, Universidad de Oriente, Venezuela, Cumaná, Estado Sucre. 181pp. [In Spanish].

Neumann, D. and Orams, M. 2005. Behaviour and ecology of common dolphins (Delphinus delphis) and the impact of tourism in Mercury Bay, North Island, New Zealand. Sci. Conserv. 254: 1-40.

Neumann, D.R. 2001. The activity budget of free-ranging common dolphins (Delphinus delphis) in the northwestern Bay of Plenty, New Zealand. Aquat. Mamm. 27(2): 121-36.

Norris, K.S. and Dohl, T.P. 1980. Behavior of the Hawaiian spinner dolphin, Stenella longirostris. Fisheries Bulletin, U.S. 77(4): 821-49.

Oviedo, L. 2008. Ecology of Neritic Odontocete Cetaceans in an Upwelling Ecosystem in the Northeast Coast of Venezuela: Delphinus sp, Sotalia guianensis. Final Technical Report 2007-2008 Term to the Rufford Small Grants for Nature Conservation. 22pp. [Available from the author]. 
Oviedo, L., Esteves, M.A., Acevedo, R., Silva, N., Bolaños-Jiménez, J., Quevedo, A.M. and Fernández, M. 2010. Abundance, distribution and behaviour of common dolphins, Delphinus spp., off north-eastern Venezuela: Implications for conservation and management. J. Mar.Biol. Assoc. U.K. 90(8): 1623-31. [Available at: $h$ ttps://doi.org/10.1017/S002531540999097X].

Pickett, S.T.A. and Thompson, J.N. 1978. Patch dynamics and the design of nature reserves. Biol. Conserv. 13(1): 27-37.

Quevedo, M.A. 2004. Distribución, abundancia relativa y comportamiento en superficie de cetáceos en la ruta Punta de Piedras-Puerto La Cruz. BSc Thesis, Universidad central de Venezuela. 96pp. [In Spanish].

Rangel, M. and Cobarrubia-Russo, S. 2008. Inventario de cetáceos en el transecto Punta de Piedra-Cumaná. Paper presented at XIII Reunión de Trabajo de Especialistas de Mamíferos Marinos de América del Sur, 7mo Congreso SOLAMAC, Montevideo, Uruguay, Octubre 2008.

Rangel, M., Esteves, M. and Oviedo, L. 2005. Long beaked common dolphin (Delphinus spp.): the dominant cetacean species associated with the complex topography in the Cariaco Trench. Paper presented at XVI Marine Mammals Biennial Conference, San Diego, California.

Rivero-Blanco, C., Yerena, E., Angel, H. and Martínez, Z. 2001. Estado Actual de los Parques Nacionales y los Monumentos Naturales de Venezuela: Visión 2001. Fundación para la Defensa de la Naturaleza. Instituto Nacional de Parques. Caracas. 15.

Rivero, K., Rumiz, D.I. and Taber, A.B. 2005. Differential habitat use by two sympatric brocket deer species (Mazama americana and M. gouazoubira) in a seasonal Chiquitano forest of Bolivia. Mammalia 69(2): 169-83. [Available at: https://doi.org/10.1515/ mamm.2005.015].

Robaina, G. 1991. Mochima 'Tierra de muchas aguas'. Caracterización de los Parques Nacionales venezolanos. Fundación ecológica Pampero - Proparques. 134pp.

Rohr, J., Hendricks, E., Quigley, L., Fish, F., Gilpatrick, J. and Scardina-Ludwig, J. 1998. Observations of dolphin swimming speed and Strouhal number. Space Nav. Warfare Syst. Ctr. Tech. Rep. 1769.

Romero, A., Agudo, A.I., Green, S.M. and Notarbartolo di Sciara, G. 2001. The cetaceans of Venezuela: their distribution and conservation status. NOAA Technical Report NMFS 151: 60pp. [Available at: http://spo.nwr.noaa.gov/re151.pdf].

Rueda-Roa, D., Mendoza, J., F., M.-K., Cárdenas, J., Achury, A. and Astor, Y. 2017. Spatial variability of Spanish sardine (Sardinella aurita) abundance as related to the upwelling cycle off the southeastern Caribbean Sea. PLoS One 12(6): 1-25. [Available at: https://doi.org/10.1371/journal.pone.0179984].

Ryan, T.J., Conner, C.A., Douthitt, B.A., Sterrett, S.C. and Salsbury, C.M. 2008. Movement and habitat use of two aquatic turtles (Graptemys geographica and Trachemys scripta) in an urban landscape. Urban Ecosyst. 11(2): 213-25. [Available at: https://doi.org/ 10.1007/s11252-008-0049-8].

Saayman, G.S., Bower, D. and Tayler, C.K. 1972. Observations on inshore and pelagic dolphins on the south-eastern Cape coast of South Africa. Koedoe 15: 1-24.

Saayman, G.S., Tayker, C.K. and Bower, D. 1973. Diurnal activitiy cycles in captive and free-ranging Indian Ocean bottlenose dolphins (Tursiops aduncus Ehrenberg). Behaviour 44: 212-33.

Sánchez-Criollo, L. and Bermúdez-Villapol, L. 2011. Análisis de las mordidas de tiburones en cetáceos varados vivos y muertos en la región nororiental de Venezuela. Paper presented at IX Congreso Venezolano de Ecología. Isla de Margarita, Venezuela. [Available from the author].

Santos, M.S., Vaske, T., Martins, T. and de Oliveira, M. 2006. Predation by a shortfin mako shark, Isurus oxyrinchus, Rafinesque, 1810, on a pantropical spotted dolphin, Stenella attenuata, calf in Central Atlantic waters. Lat. Am. J. Aquat. Mam. 5(2): 141-44. [Available at: https://doi.org/10.5597/lajam00106].

Selzer, L.A. and Payne, P.M. 1988. The distribution of white-sided (Lagenorhynchus acutus) and common dolphins (Delphinus delphis) vs. environmental features of the continental shelf of the northeastern United States. Mar. Mamm. Sci. 4(2): 141-53. [Available at: https://doi.org/10.1111/j.1748-7692.1988.tb00194.x].

Shane, S.H. 1990. Behavior and ecology of the bottlenose dolphin at Sanibel Island, Florida. pp.245-66. In: S. Leatherwood and R.R. Reeves (eds). The Bottlenose Dolphin. Academic Press, San Diego, Californa. 653pp.

Shane, S.H., Wells, R.S. and Würsig, B. 1986. Ecology, behavior and social organization of the bottlenose dolphin: a review. Mar. Mamm. Sci. 2(1): 34-63. [Available at: https://doi.org/10.1111/j.1748-7692.1986.tb00026.x].

Sokal, R.R. and Rohlf, F.J. 1995. Biometry: The Principles and Practice of Statistics in Biological Research. 3rd ed. W.H. Freeman \& Co., New York. 887pp.

Stockin, K.A., Binedell, V., Wiseman, N., Brunton, D.H. and Orams, M.B. 2009. Behavior of free-ranging common dolphins (Delphinus sp.) in the Hauraki Gulf, New Zealand. Mar. Mamm. Sci. 25(2): 283-301. [Available at: https://doi.org/10.1111/j.1748-7692.2008.00262.x].

Stockin, K.A., Pierce, G.J., Binedell, V., Wiseman, N. and Orams, M.B. 2008. Factors affecting the occurrence and demographics of common dolphins (Delphinus sp.) in the Hauraki Gulf, New Zealand. Aquat. Mamm. 34(2): 200-11. [Available at: https://doi.org/10.1578/ AM.34.2.2008.200].

Suárez, M.M. and Bethencourt, C. 1994. La Pesca Artesanal en la Costa Caribe de Venezuela. Fundación Biggott, Caracas. 270pp.

Swihart, R. and Slade, N. 1985. Testing for independence of observations in animal movements. Ecology 66(4): 1176-84. [Available at: https://doi.org/10.2307/1939170].

Tavares, M., Moreno, I.B., Siciliano, S., Rodriguez, D., De O. Santos, M.C., Lailson-Brito Jr, J. and Fabian, M.E. 2010. Biogeography of common dolphins (genus Delphinus) in the southwestern Atlantic Ocean. Mamm. Rev. 40(1): 40-64. [Available at: https://doi.org/10.1111/ j.1365-2907.2009.00154.x].

van Schaik, G.P. and van Hooff, J.A. 1983. On the ultimate causes of primate social systems. Behaviour 85(1): 91-117. [Available at: https://psycnet.apa.org/doi/10.1163/156853983X00057].

Viddi, F.A. and Lescrauwaet, A.K. 2005. Insights on habitat selection and behavioural pattersn of Peale's dolphin (Lagenorhynchus australis) in the Strait of Magellan, southern Chile. Aquat. Mamm. 31: 176-83. [Available at: https://doi.org/10.1578/AM.31.2.2005.176]. 
Visser, I.N. 1999. Propellor scars on, and well known home range of two Orca (Orcinus orca) in New Zealand waters. New Zeal. J. Mar. Freshw. Res. 33: 635-42. [Available at: https://doi.org/10.1080/00288330.1999.9516906].

Wedekin, L.L., Daura-Jorge, F.G. and Simões-Lopes, P.C. 2002. Desenhos de unidades de conservação marinhas com cetáceos: estudo do caso do boto-cinza Sotalia guianensis, na Baía Norte de Santa Catarina, sul do Brasil. Paper presented at III Congresso Brasileiro de unidades de conservação.

Wedekin, L.L., Daura-Jorge, F.G. and Simões-Lopes, P.C. 2010. Habitat preferences of Guiana dolphins, Sotalia guianensis (Cetacea: Delphinidae), in Norte Bay, southern Brazil. J. Mar. Biol. Assoc. U.K. 90(8): 1,561-70. [Available at: https://doi.org/10.1017/ S0025315410001414].

Wilson, B., Hammond, P.S. and Thompson, P.M. 1999. Estimating size and assessing trends in a coastal bottlenose dolphin population. Ecol. Appl. 9: 288-300. [Available at: https://doi.org/10.2307/2641186].

Wilson, B., Thompson, P.M. and Hammond, P.S. 1997. Habitat use by bottlenose dolphins: seasonal distribution and stratified movement patterns in the Moray Firth, Scotland. J. Appl. Ecol. 34: 1365-74. [Available at: https://doi.org/10.2307/2405254].

Würsig, B. 1986. Delphinid foraging strategies. pp.347-59. In: R.J. Schusterman, J.A. Thomas. and F.G. Wood (eds). Dolphin Cognition and Behavior: A Comparative Approach. Lawrence Erlbaum Associates, Hillsdale, New Jersey. 393pp.

Würsig, B. 1989. Cetaceans. Science 244(4912): 1550-57.

Würsig, B. and Würsig, M. 1979. Behavior and ecology of the bottlenose dolphin, Tursiops truncatus, in the South Atlantic. Fish. Bull. 77: 399-412.

Zar, J.H. 1996. Biostatistical Analysis, 3rd Edition. Prentice-Hall, Inc., New Jersey. 662pp. 